Likewise, the reliable performance decrement on Extinction Day 1 for each group except 50SA presumably reflected the tendency of nonshock aftereffects to elicit vigorous escape behavior for 50SA. Unfortunately the effects of 50SA were transient. Later extinction data showed a reliable decrement in 5OSA's performance similar to that of other groups. This decrement may have reflected the modification of nonshock aftereffects for $50 \mathrm{SA}$ by successive extinction trials.

\section{Time-dependent learning deficit caused by hydroxylamine}

\author{
STANISLAV REINIS \\ Department of Physiology, Ghana Medical School, Accra, Ghana*
}

The effect of 0.5-M hydroxylamine injected intracranially on a passive-avoidance task was followed in mice. Hydroxylamine administered $24 \mathrm{~h}$ before the acquisition trial or earlier had no effect on performance of animals. Hydroxylamine injected $2 \mathrm{~h}$ before the acquisition trial impaired the performance of animals tested $24,48,72 \mathrm{~h}$, or 1 week later. Hydroxylamine injected 1,2 , or $24 \mathrm{~h}$ later interfered with the performance of animals, too. The later hydroxylamine was injected, the later the impairment of performance of animals appeared. The effect of hydroxylamine is probably associated with the "mutagenic" action of the drug on activated DNA.

In our previous papers (Reinis, $1970 \mathrm{a}, \mathrm{b})$, we described the effect of hydroxylamine on retention of two different learning situations-alimentary conditioning and learned preference to one arm of a water maze. We associate the effect of hydroxylamine on learning with the metabolic disturbances of the affected nerve cells, from which the transcription of changed DNA may be one of the important constituents. Hydroxylamine is bound to several nucleotides of activated derepressed DNA and causes "misreading" of the code. Abnormal proteins are synthetized (Beguin \& Kepes, 1963), which may be responsible for the delayed effect of the drug.

In the present paper we tried to correlate the interval between acquisition trial and hydroxylamine injection with the time of appearance of the behavioral

*Present address: Department of Psychology, York University, 4700 Keele Street, Downsview 463, Ontario, Canada.
RIFERENCES

BL OON. J. M., \& CAPALDI, E. J. The behavior of rats in relation to complex patterns of partial reinforcement. Journal of Comparative \& Physiological Psychology, 1961, 54, 261-265.

IRANCHINA, J. J. Transfer of escape training. Journal of Comparative \& Physiological Psychology, 1968, 65, 175-178.

FRANCHINA, J. J. Intertrial intervals and shock schedules in escape training. Journal of Comparative \& Physiological Psychology, 1969.67, 510-515.
University of Ghana Medical School in Accra. Rat males, weighing $25.30 \mathrm{~g}$ and aged at least 2 months, were used for the experiment. The mice were brought 4.5 days before the experiment into an air-conditioned room $\left(23^{\circ} \mathrm{C}\right)$ and kept in this room up to the end of the experiment.

The apparatus consisted of a covered wooden chamber $28 \times 28 \times 25 \mathrm{~cm}$. A narrow chamber, $16 \times 11 \times 28 \mathrm{~cm}$, made from semitransparent acrylic plastic, was attached to the wooden box. The wooden chamber was provided with a grid floor wired to a power supply that administered a $4.5-\mathrm{mA}, 100-\mathrm{Hz}$ footshock to the animal when it entered it through a $7-\mathrm{cm}$-diam hole connecting the two chambers. The mice were placed into the smaller transparent lighted chamber from which they stepped spontaneously into the bigger dark one. The interval between the placement of the animal into the lighted compartment and its entry through the hole into the darkened chamber (response latency) was measured in this acquisition trial.

The $0.5 . \mathrm{M}$ hydroxylamine hydrochloride, adjusted by sodium hydroxide to $\mathrm{pH} 7.35$, was injected intracranially in the dose of 10 microliters towards each hemisphere. For control injections, 0.5-M saline was used. The mice were slightly narcotized with ether, and the skin of the head was cut in the middle line. A thin injection needle was advanced through the temporal muscle. This prevented leakage of the fluid from the skull.

Groups of animals were injected 2 weeks, 1 week, $72,48,24$, and $2 \mathrm{~h}$ before the acquisition trial and 1,2, 4, and $24 \mathrm{~h}$ after the acquisition trial. Each injection group was split into four test-time groups, the first being tested $24 \mathrm{~h}$, second $48 \mathrm{~h}$, third $72 \mathrm{~h}$, and fourth 1 week after the acquisition trial. Each animal was tested only once. There were 12 animals in each test-time group. The test trial was conducted in essentially the same fashion as the acquisition trial. The latency of entering the dark compartment was measured with a stopwatch. A 300-sec cut-off time was used for the test trial

Table 1

Response Latency in First (Acquisition) Trial in Mice Injected by Hydroxylamine

\begin{tabular}{|c|c|c|c|c|}
\hline \multirow[b]{2}{*}{ Injection } & \multicolumn{2}{|c|}{ Saline } & \multicolumn{2}{|c|}{ Hydroxylamine } \\
\hline & $\begin{array}{c}\text { Number of } \\
\text { Animals }\end{array}$ & $\begin{array}{l}\text { Time in } \\
\text { Seconds }\end{array}$ & $\begin{array}{c}\text { Number of } \\
\text { Animals }\end{array}$ & $\begin{array}{l}\text { Time in } \\
\text { Seconds }\end{array}$ \\
\hline No injection before trial & 360 & & $19.1 \mathrm{sec}$ & \\
\hline 2 weeks before & 24 & 21.1 & 24 & 18.3 \\
\hline 1 week before & 24 & 22.7 & 24 & 16.7 \\
\hline $72 \mathrm{~h}$ before & 48 & 17.8 & 48 & 20.0 \\
\hline $48 \mathrm{~h}$ before & 48 & 15.3 & 48 & 23.0 \\
\hline $24 \mathrm{~h}$ before & 48 & 21.6 & 48 & 25.2 \\
\hline $2 \mathrm{~h}$ before & 48 & 17.4 & 48 & 17.4 \\
\hline
\end{tabular}


Table 2

Number of Mice That Did Not Enter the Dark Space in the Second (Testing) Session of Passive-Avoidance Task

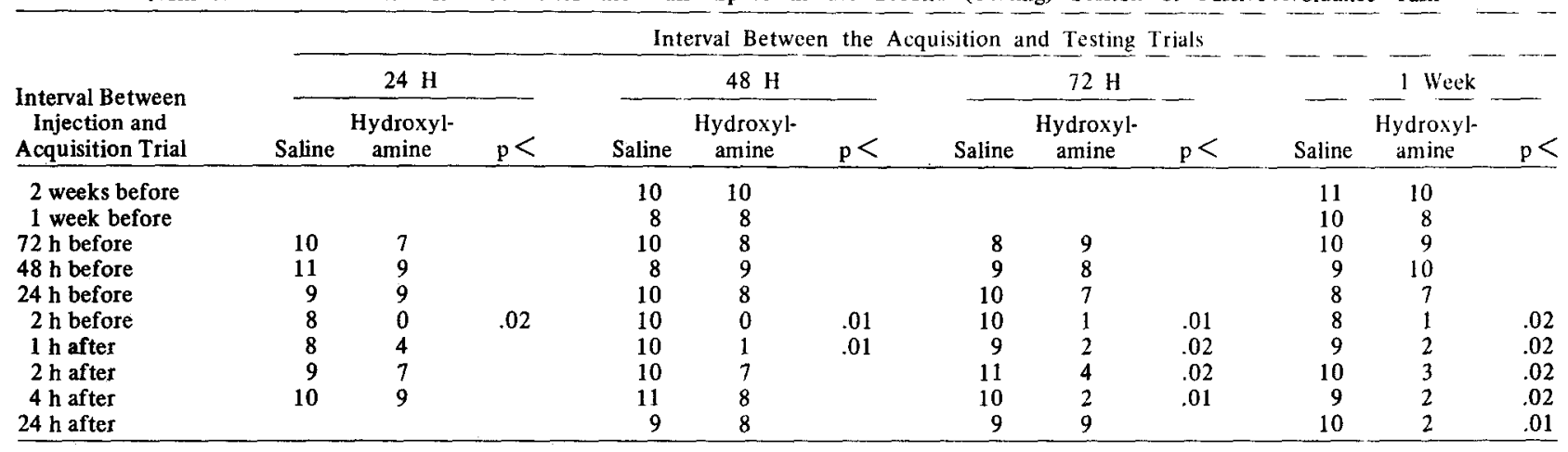

response latency. There were always 12 animals in one group. The number of mice that entered the dark chamber earlier than $300 \mathrm{sec}$ was evaluated statistically by a chi-square test.

\section{RESULTS}

Table 1 demonstrates the average response latency in the first (acquisition) trial. There are no statistically significant differences between the intact mice without any injection and mice injected intracranially by hydroxylamine or saline.

In Table 2 the retention of passive avoidance in mice affected by hydroxylamine is shown. The injection of hydroxylamine performed from 2 weeks to $24 \mathrm{~h}$ before the acquisition trial is ineffective. Hydroxylamine administered $2 \mathrm{~h}$ before the acquisition trial has a very high effect on performance of animals in the testing trial; this may be demonstrated as early as $24 \mathrm{~h}$ after the training and persists up to the testing session 1 week after training.

Hydroxylamine injected $1 \mathrm{~h}$ after the acquisition trial affects the performance of the animals within $48 \mathrm{~h}$ after injection. The effects of hydroxylamine injected 2 or $4 \mathrm{~h}$ after the first trial appear for the first time $72 \mathrm{~h}$ after injection. If we injected hydroxylamine $24 \mathrm{~h}$ after training, the effect appeared only in one group tested 1 week after the acquisition trial.

\section{DISCUSSION}

Learning, and maybe permanent retention of the memory trace, is accompanied with an increased production of ribonucleic acids in the corresponding nerve cells (Hyden, 1967). One of the factors leading to the increased RNA production may be activation or derepression of a part of genome (John, 1967). However, this activation cannot be proved directly. Direct proof of the activation of DNA is possible, e.g., by hybridization methods (e.g., Machlus \& Gaito, 1968). However, we suppose that indirect methods may also present suitable results. Hydroxylamine has numerous effects on cell metabolism; it may cause splitting of existing proteins, changes in energetic metabolism, in RNA, but it also acts as a mutagen. It alters the reading and translation of nucleotides constituting DNA (Bose \& Gothoskar, 1965). It was found that hydroxylamine affects selectively activated DNA, leaving behind repressed parts of DNA molecules. This was the reason we started the testing of the effect of hydroxylamine on learning. In our previous paper (Reinis, 1970b) we found that hydroxylamine affected the retention of learned preference in the water maze, but the impairment was probably not due to occult seizures, methemoglobinemia, or general illness. The motor coordination on a rotating rod was not affected. Exploratory activity was slightly lower up to $24 \mathrm{~h}$ after the injection but not later. In this paper we presented also one group of results showing that the behavioral changes are probably not caused by the changes of general activity. Average response latency in the acquisition trial was not substantially longer in mice injected by hydroxylamine. In another paper, where we tested the effect of hydroxylamine on alimentary conditioning, we demonstrated that hydroxylamine injected 2 weeks, 1 week, or 1 day before the first training session has no effect on the speed of training. On the other hand, hydroxylamine injected after the last, 15 th, training session caused the impairement of retention (Reinis, 1970a). The longer the time elapsed between injection and testing of the effect, the deeper was the impairment.

In the present paper we demonstrate again similar relations. Hydroxylamine injected $24 \mathrm{~h}$ before training and earlier is ineffective. Injections performed $2 \mathrm{~h}$ before training or after training interfere with the retention. The drug administered $2 \mathrm{~h}$ before the acquisition trial, and therefore probably still present in the tissue at the moment of training, is mostly effective. The longer the time between training and injection, the later the effect appears.
The explanation of the mechanism of the hydroxylamine effect on learning is hardly possible at the moment. Numerous biochemical changes that appear in the cells immediately after the administration of the substance probably do not contribute directly to the impairment of performance of animals. The delay of the effect may mean that some very basic function of the cell is affected, which only indirectly and slowly changes its vital processes.

Therefore, it is possible to assume that hydroxylamine affects derepressed DNA of the nerve cell; defective RNA and proteins are then produced which slowly replace the normal constituents of the cell. The sooner after learning hydroxylamine is administered, the quicker the deficient RNA replaces the normal functioning RNA and proteins.

However, this hypothesis still has to be proved by direct tests detecting repressed or derepressed DNA of the nerve cell and turnover of RNA and proteins in the nervous tissue following administration of hydroxylamine.

\section{REFERENCES}

BEGUIN, S., \& KEPES, A. Effects of hydroxylamine on biosynthetic processes in $\mathrm{E}$. coli. Comptes Rendue, 1963, 258, 2690-2693.

BOSE, S., \& GOTHOSKAR, B. P. Studies on biological macromolecules: Effect of hydroxylamine on nucleic acid and protein synthesis in mammalian cells in vitro. Experimental Cellular Research, 1965, 40, 619-629.

HYDÉN, H. The neuron. Amsterdam, London, New York: Elsevier, 1967.

JOHN, E. R. Mechanisms of memory. New York: Academic Press, 1967.

MACHLUS, B., \& GAITO, J. Unique RNA species developed during a shock avoidance task. Psychonomic Science, 1968, 12, 111-112.

REINIS, S. Delayed learning deficit produced by hydroxylamine. Physiology \& Behavior, 1970a, 5, 253-256.

REINIS, S. Effect of hydroxylamine on maze leaming in mice. Journal of Comparative \& Physiological Psychology, 1970b, in press. 